\title{
East Africa Refugee Crisis: Causes of Tensions and Conflicts between the Local Community and Refugees in Kakuma Refugee Camp, Kenya
}

\author{
Ms Jecinta Anomat Ali (Corresponding Author) \\ Institute of Diplomacy and International Studies, Rangsit University \\ 52/347 Muang Ake, Paholyothin Road \\ Lakhok, Pathumthani 12000, Thailand \\ E-mail: jacyanomat@gmail.com \\ Dr. Witchayanee Ocha \\ Institute of Diplomacy and International Studies, Rangsit University \\ 52/347 Muang Ake, Paholyothin Road \\ Lakhok, Pathumthani 12000, Thailand \\ E-mail:witchayaneeocha@gmail.com
}

Received: September 22, 2017 Accepted: January 18, 2018 Published: January 20, 2018

doi: $10.5296 /$ jsss.v5i1.12512

URL: http://doi.org/10.5296/jsss.v5i1.12512

\begin{abstract}
The study investigated the refugee and host community conflicts in Kakuma refugee camp located in Turkana County, in the North-West parts of Kenya. The study classified factors causing tension and conflicts between the refugees and the local community into four main categories; political and security, limited resources, social welfare and socio-cultural factors. The following three main outstanding points explains what causes tensions and conflicts; firstly, the host community feels refugees are more economically privileged because of the aid they get from refugees aid organizations. Secondly, the host community population has been outnumbered by the refugees' population that has created fear and tension since the host can do less to stop refugees from doing anything harmful to them. Thirdly, competition as a result of the limited resources such as land, water and wood collection in the penurious
\end{abstract}


semi-arid area where the refugees and host community lives. This study recommends that in order to foster a better existence amongst the refugees and host community, refugees' agencies should tailor their programs to development of both the host community and refugees as suggested in Refugee Aid and Development Theory.

Keywords: Refugee crisis, Investigating, Local community, Tension, Conflicts, Kakuma

\section{Introduction}

The provision of safe havens to refugees by many countries is not a new thing, recent global events have been shading lights on the impact refugees have on the living conditions of the host communities for example; resistance of relocating Syrian refugees to Germany by local communities, the decision of European Union to stop migration into Europe, president Donald Trump of United States of American campaigns rhetoric, about the effect of immigrants on host community and the recent signing of executive order to bar more than 6 Muslim countries migrants and visitors from entering USA (Paige, 2017). The refugees and host countries outcry rotates around issues such as economy, environment, culture and security. The current refugee crisis appears to pass the "deaf ears" of the developed nations since they are currently hosting the smallest percentage of the total refugees' population in the World. This explains why developing countries such as Lebanon, Jordan, Ethiopia, and Kenya are home to nearly 90 per cent of the World's refugees (UNHCR, 2016).

The developing nations such as Ethiopia, Uganda and Kenya to some degree have become the unpremeditated "shock absorbers" for the ever increasing conflicts, insecurity, and weak governance in the neighboring countries such as Somalia and South Sudan. The developed countries' refusal to fully support refugees' settlement and funding recently prompted the government of Kenya to announce plans to close down Dadaab refugee camp located to the Northeast border of Kenya and Somalia (Tom, 2016). The Kenya government gave the following three main reasons for closing Dadaab refugee camp; first, the World is reluctant to share the burden of hosting refugees especially in funding and helping the refugees to settle elsewhere permanently. Second, hosting refugees has become expensive resulting to high competition to the already limited resources available. This competition over the limited resources such as water, wood, food and social amenities has led to tensions and conflicts between the host community and the refugees. Third, hosting of refugees has resulted to recent witnessed terrorists attacks on Kenyan soils, for example; the killing of over 147 Garissa University college students in April, 2015 (MyGov, 2015), the killing of over 67 people at Westgate shopping mall in September, 2013 (Anderson \& McKnight, 2014) and various continuous attacks especially in North Eastern and Coastal regions. This was in addition to August 1998 twin bomb blasts that killed over 224 people and wounded over 5,000 at the United States embassies in Nairobi, Kenya and Dar Es Saalam, Tanzania. Kenya suffered the most since it accounted for 213 dead while Tanzania had the least since only 11 people who were killed in the blast (Champagne et al, 2005).Therefore, the government of Kenya blames all these series of attacks majorly in hosting refugees from many countries especially of Somalia origin. 


\subsection{Refugees' Global Trend}

The world is presently experiencing unmatched refugee influx which is as a result of political, economic, and religious conflicts and internal wars. Refugees' problem ceased being a regional problem since it has become a global problem. Syrian crisis is caused by political and religious misunderstanding forcing many to flee Syria. In addition, changes in climate that is causing many places around the World to receive unreliable rainfall or in some places it brings prolonged droughts that make farming which is the traditional way of livelihood almost impossible to practice. The people living in such areas are forced to migrate to areas or countries where they are able to get jobs or even practice farming and this in itself results to tension and conflicts. It is estimated that there are over 65.6 million forcibly exiled persons worldwide and 22.5 million are refugees. There are over 10 million stateless people around the World and it estimated in 2016 alone 189,300 were resettled. It surprising that 55 per cent of refugees worldwide came from three countries namely; Syrian 5.5 million, Afghanistan 2.5 million and South Sudan 1.4 million (UNHCR, 2017a). In South East Asia for example, there are 99,930 refugees living in nine camps in Thailand as of September, 2017 UNHCR report and majorities of these refugees are ethnic minorities from Myanmar who have been fleeing conflict in their country for nearly 30 years now (UNHCR, 2017b).

The political crisis in the northern Africa countries such as Libya, Tunisia and Egypt is causing refugees to flow into Europe via Mediterranean Sea. Europe has been witnessing the highest numbers of refugees' influx and most of them came from Syria, Somalia, Libya, Tunisia and Egypt. The refugees' crisis has made some European nations to put border walls or fences and strict border checks so as to bar refugee from entering their countries, UNHCR (2015). The refugee influx in western nations has become a political and economic agenda used during presidential, prime minister or Member of Parliament's campaigns. There are those who support refugees' settlement and those who are against it. The most affected countries in Europe current includes; Germany, France, Spain, Greece, and Turkey.

\subsection{Refugees in Kenya}

Kenya hosting refugees is not a recent thing, it started in early 1970s when Kenya hosted Ugandans displaced by the political coups and tribal regimes of the time. The regional political and economic crises observed in 1990s both in the horn of Africa and central African nations changed enormously refugees' state of affairs in Kenya. This is the time Kenya received refugees from Somalia, Ethiopia, South Sudan and Democratic Republic of Congo. The refugees from Ehiopia came to Kenya after the fall of the Derg regime in 1991 which had failed to stop political persecution even though they arrived later. The refugees from Somalia and South Sudan (then Sudan) came to Kenya in large numbers after the toppling of president Siad Barre' government in 1992 and entering of 40,000 South Sudan boys commonly referred as "Lost Boys" to Kenya in 1992 due to political and religious war between Khartum government in the North and the rebels - the Sudan People's Liberation Movement (SPLM) in the south of country with their headquarter in Juba. The number of refugees even increased further when Rwandanese came to Kenya after Rwanda genocide that happened in 1994 and lastly, Kenya also hosted refugee from Democratic Republic of Congo (DRC) who are victims of decade's long conflict between Kinshasa government and Congolese rebel factions. 


\section{MInstitute ${ }^{\text {Mink }}$}

The refugees and asylum seekers in Kenya come from over ten countries, namely; Somalia, South Sudan, Ethiopia, Burundi, DR Congo, Sudan, Eritrea, Uganda, Rwanda and other nationalities. These refugees live in three designated camps which includes; Dadaab, Alinjugur and Kakuma. In addition, the government of Kenya has accepted some refugees who have resources to live in urban cities such as Nairobi, Ruiru and Eldoret. This is why Kenya is home to more than 584,989 registered refugees and Asylum seekers (See Table 1). Dadaab and Kakuma camp accounts for 38 and 31 per cent respectively of refugees living in Kenya. This study was limited to Kakuma refugee camp which is the second largest refugee camp in Kenya hasting more than 180,000 refugees after Dadaab refugee camp that hosts more than 224,000 refugees (UNHCR, 2015).

Table 1. Refugee population in Kenya

\begin{tabular}{llll}
\hline No. & Refugee Location & Population & Percentage \\
\hline 1 & Dadaab camp & 224,884 & $38 \%$ \\
2 & Kakuma camp & 180,674 & $31 \%$ \\
3 & Alinjugu camp & 127,674 & $22 \%$ \\
4 & Nairobi (Urban Refugees) & 51,757 & $9 \%$ \\
\hline & Total & $\mathbf{5 8 4 , 9 8 9}$ & $\mathbf{1 0 0 \%}$ \\
\hline
\end{tabular}

Source: Boundaries-UNCS, Statistics, UNHCR Kenya (2015).

\subsection{Kakuma Refugee Camp}

Kakuma refugee camp in Kenya presently host refugees and asylum seekers from over 10 countries, namely; South Sudan, Somalia, Ethiopia, Democratic Republic Congo, Burundi, Sudan, Eritrea, Uganda, Rwanda and other nationalities. Kakuma refugee camp is divided into four settlements of clusters (zones), namely; zone I, II, III and IV. The camp is approximately $15 \mathrm{~km} 2$ with a capacity of 125,000 persons which is located on the outskirts of Kakuma town which is Turkana West District headquarter in the larger Turkana County. The houses in the camp are mostly built by; mud bricks, wood, cane/sticks and sometimes with canvas tents provided refugee aid organizations. Kakuma refugee camp was established first in 1992 to settle about 40,000 Sudanese youth commonly referred as "lost boys" who returned to Sudan from Ethiopia after the resignation and fleeing to exile of Mengistu Haile Mariam who was Ethiopia's head of state (Aukot, 2003; UNHCR, 2016).

Refugee camps in Kenya are managed by refugee aid organizations and national government agencies headed by the United Nations High Commission for Refugee (UNHCR) and Department of Refugee Affairs (DPA) respectively. The main relief organizations operating at the Kakuma refugee camp includes; World Food Programme (WFP) and the Lutheran World Federation (LWF) which are responsible for providing relief food and facilitate its distribution; the International Rescue Committee (IRC) which provides health services; the National Council of Churches of Kenya (NCCK) which provide housing solutions for the refugees, and lastly, the International Organization for Migration responsible for settlement 
of refugees; Jesuit Refugees Services which provide education services to the refugees (Oka, 2014), amongst other organization.

\subsection{Problem Statement}

The Refugee-Host communities' tensions and conflicts have escalated in the recent past around the globe. The tension and conflict is majorly caused by the shared limited resources and lack of Refugee-Host Community projects. In most cases the Host-Community view refugees as threats to their limited resources which include; land, wood, jobs and water especially as refugee population increases. In the Kenyan context, the host community (the Turkana people), belief that refugees receive special treatment since they are unable to access essential services such as education, health, water and more importantly getting food which is readily available to refugees in Kakuma Camp.

It is clear that migration of refugees in large numbers started in 1990s whereby refugees from Somalia, South Sudan (then Sudan), Ethiopia and Democratic Republic of Congo. This means that refugees from these nations have been in Kenya for over two decades now. This has resulted to the competition of the already limited resources and social amenities. The competition here led to tensions and conflicts between the refugees and the host community in this case the 'Turkana People.' A part from scramble for limited resources and social amenities, differences in cultural and religious practice between the refugees and the host community as resulted to both cultural and religious conflicts. Kenya is facing an ever-increasing number of refugees and asylum seekers driven out from their homes nation by several political and economic conflicts witnessed in the larger East and Central Africa countries.

These refugees for over 20 years have lived with local community (The Turkana) around Kakuma refugee camp which has been a relationship of both conflicts and bitter co-existence. The host community blame refugees for the scarcity of resources, for example, limited factors shared such as land, forests, water and food that used to be available to them are diminishing or hardly found. There is little information about what are the key causes of conflicts and whether there are measures put in place to solve these conflicts. The question therefore is, how are tensions and conflicts resolved and by who? Therefore, this paper found it crucial to find causes of tensions and conflicts between refugees and the host community. In addition, the papers avails current solutions put in place and recommendations to improve the situation.

\subsection{Goal and Objectives}

The main goal of this paper was to find out causes of tensions and conflicts between refugees and host community in Kenya. The study limited itself to Kakuma refugee camp located in Turkana County although refugees in Kenya live in three refugee camps namely; Dadaab, Alinjugur, Kakuma and some live in Kenya's urban centres such as Nairobi, Eldoret and Ruiru.

\section{Literature Review}

The current refugees' worldwide inflow and the declining refugees' support from developed countries has become a sensitive disquiet to the countries hosting refugees such as Kenya. There is no doubt; these countries are now overstrained by refugees' hosting problems that affect not only the economy but it also affects their political stability. The influence of 
refugees' has been studied and investigated by various researchers although touching on different contexts (Akim, 2014; Ikanda, 2008; Whitaker 2002; Kuhlman, 1991). The conflicts between refugees and the host community has been subject of discussion in different academic forums and researches. What comes out clearly is that most of these discussion are in agreement that refugees in host nations are seen as an economic burden especially during worse economic times and therefore, resulting to tensions and conflicts, (Akim, 2014; Martin, 2005).

The tensions and conflicts witnessed between the host community and the refugees are by larger percentage caused by limited and scarce natural resources that are shared (Kumssa, Jones, \& Herbert, 2009). In addition, the conflict is caused by an equal treatment between the refugees and the host community by both the aid agencies and the government. It is reported that the host community does not get aid or support the same way refugees do through refugee agencies led by UNHCR and this implies that refugees get the chance to access better education, health, and basic livelihood which the host do not get (Betts, 2009). Countries such as Ethiopia, Kenya and Uganda alleged that Sudan refugees (now South Sudan) as a burden especially when the host countries were undergoing economic stagnation. The relief aid given to refugees by aid agencies made the issues complex and worst since refugees were treated special than the host, Ek and Karadawi (1991). This was echoed by Adisa (1996) who argued that refugee-host relations in the Great Lakes region became a burden not only to the host community but to host country as well. According to Atim (2013), arrival of refugees to the host country brings with it economic, environmental, socio-cultural, and security challenges. The smooth operations of refugee aid organizations such as UNHCR is being hampered by bad refugee-host relations in their attempt to protect and seek permanent solutions to refugee-host good co-existence (Aukot, 2003). Therefore, this study found it necessary to seek answers on what causes tensions and conflicts around the refugee camps right from the victims in this case the refugees and the host community.

\subsection{Theoretical Review (Refugees'Theory)}

The following theories (Refugee Aid and Development (RAD) theory and Elias' Theory) were used to elucidate refugees and host community co-existence which characterized by majorly conflicts and tensions.

Refugee Aid and Development (RAD) Theory, explains complex links and interactions between development and refugee subjects which should focus mainly on facilities capacity in hosting refugees on top of recognizing refugees' needs as well. It is development oriented concepts that puts into consideration both the host community and the refugees (Betts, 2004; Morfor, 2012). The theory claims that the incoming refugees are considered as a burden to the host nation and the community meaning they are not considered as an opportunity. In order to develop peaceful and good relations between the refugees and the host community, both parties need to be involved in various projects and operations (Kuhlman, 1990). RAD approaches tries to remove the impression that refugees are a burden since it transforms refugees from the so called "'a burden" to a self-sufficient status. In summary there is need for aid agencies and the host government to allow both refugees and host community to share resources equally and indiscriminately since in most cases the host communities feel left behind especially in provision of amenities only to the refugees behind. 
Elias' Theory on the hand this theory by Elias and Scotson, refers to an examination of suburban neighborhood which they named Winston Parva set up within the outskirts of an industrial town and it had less than 5,000 populaces who formed a dense community with its own factories, schools, churches, shops and clubs (Hogenstijn, Daniel \& Kees, 2008). Elias and Scotson started by studying demographic and social factors such as class, income, work and origin of the population so as to establish why there was social inequality between the old residents (Established) and the newcomers (Outsiders) in the zones established.

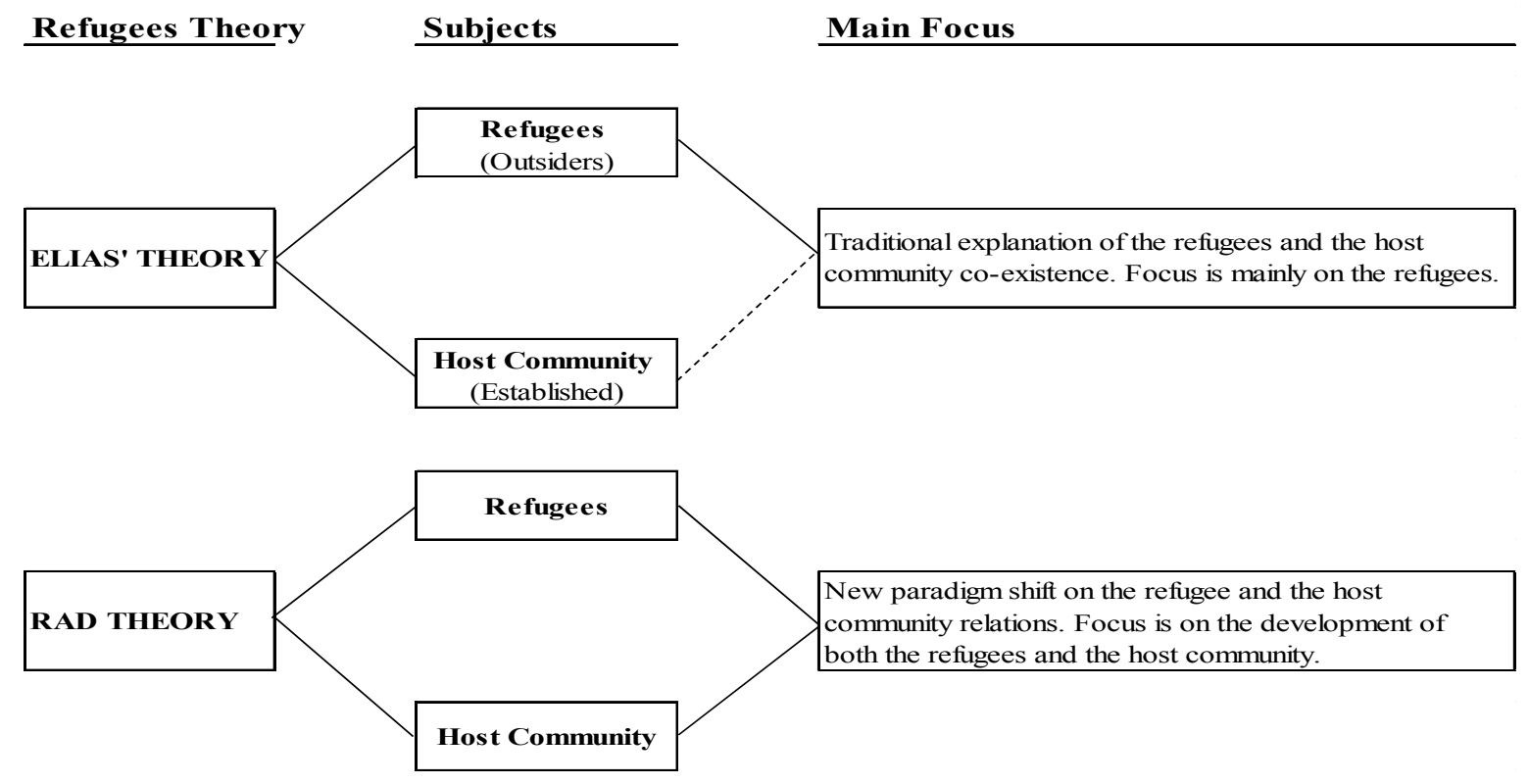

Figure 1. Refugees theories and focus

Note: 1. RAD refers to Refugee Aid and Development Theory

2. - Indicates strong focus by Aid agencies and host government

3. ---- Indicates weak focus and support by Aid agencies and host government

Conflicts between the residences occurred because the old residents 'representing the host community' had an hope that the newcomers 'representing the refugees' would finally familiarize with the norms and values of the host community rather than behaving as they were before (Tollebrandt \& Sophia, 2013). It is reported that the outsiders (refugees) did not adapt to the new way of living in their new area and were isolated compared to the established (the host community). Therefore, this study used Elias' Theory to explain the impact of refugees to the host community that in most cases results to tensions and conflicts. This theory tries to highlight how refugees are treated when they find themselves in the host nation. What is clear is that the host community is not in the focus of aid agencies and host country especially in providing aid assistance. Elias Theory concept represents the old ideology of focusing help to refugees and leaving out the host community from it which in itself is a source of conflict. 


\subsection{Refugees' Rights and Protection in Kenya}

Kenya supports and affirms human rights conventions, for example; the International covenant on economic, social and cultural rights of 1966, the elimination of all forms of discrimination against women of 1979 and finally, the statute of the international criminal court of 1998. Kenya has not only supported both international and regional refugees' rights but it has also domesticated them to its laws. In addition, Kenya supports 1969 Organization of African Unity (OAU) Convention on Refugees that tries explains how refugees' rights can be protected and also asserted the protocol relating to the Status of Refugees of 1967. On top of that Kenya supports UN Refugee Convention of 1951 that defines a refugee as;

"A person who owing to a well-founded fear of being persecuted for reasons of race, religion, nationality, membership of a particular social group or political opinion, is outside the country of his nationality and is unable or, owing to such fear, is unwilling to avail himself of the protection of that country; or who, not having a nationality and being outside the country of his former habitual residence as a result of such events, is unable or, owing to such fear, is unwilling to return to it."

The convention governing the specific aspects of refugee problems in Africa, in 1969 besides accepting the UN definition extended the definition to include people escaping from external violence, internal civil strife, or events seriously disturbing public order in African countries (Kirui \& Mwaruvie, 2012). Typically, arriving refugees into a new area or country are registered and be recognized as people fleeing their homeland. They are referred to as asylum seekers at first and are then handed to UNHCR after going through registration (Atim, 2013; UNHCR, 2010).

Kenya has been one of the counties' in Africa championing for refugees' rights, support and settlements. Kenya as seen from the above paragraph since independence has asserted and agreed on various human rights conventions, international refugees' rights, and human rights. Kenya's 1963 Constitution had no detailed references laws concerning refugees until 1972 whereby the Miscellaneous Amendment Act No. 6 of 1972 that amended the Immigration Act introducing the refugees' protection. Kenya domesticated international and regional human rights and refugees laws especially in the Refugee Act of 2006 (Muigua, 2006). The Refugees Act 2006 took a decade for it to be accepted, there was delay in drafting the Act. This refugee act explains intensely the management of refugees' reception, entry and protection of refugees in Kenya. There is no doubt, the 2006 Refugees Act and the 2009 Refugee Regulations in Kenya are as a result of domestication of regional and international laws on refugees' rights. The 2010 Constitution of Kenya, even though not explicit, it confers citizenship to refugees through marriages and offers refugees' protection.

\section{Research Methodology}

The qualitative research approach was used in this study to unearth refugees-host tensions and conflicts in the refugee camp. This method of research creates concrete and theoretical truths about human life which can originate in the pragmatisms of daily survival, Jorgensen (1989). Therefore, this method assists in describing and understanding the social occurrences in terms of the meaning people bring to them since the study enquiries are planned through flexible methods allowing interaction with the people involved to an extent that is necessary 


\section{Macrothink

to understand what happens in the field. The problem under study is therefore analysed in depth, diverse viewpoint and within the confines of specific background. This is in relation to case study which is vital for studying complex phenomena since it shows a variety of perspectives of the same phenomena investigated. This explains why qualitative approach is richer in collecting information and provides deeper understanding of the problem under study.

\subsection{Target Population and Data Collection}

The study targeted local residents (the Turkana people) and the refugees living inside Kakuma refugee camp. The refugee population in Kakuma refugee camp is estimated to be over 180,674 both registered refugees and asylum-seekers (UNHCR, 2015). The target populace of the host community comprises of the adult and the youth who live near Kakuma refugee camp who are estimated to be 90,000 persons as per Kenya's 2009 census. Data was collected through direct communication with the host community and the refugees through conducting interviews, focus groups, and observations. In this study collecting secondary information or data was essential especially in understanding what were the current measures put to reduce the tensions and conflicts around the camp.

The sources of the secondary data used in this study was obtained from the published journals, textbooks, thesis/dissertations, UNHCR websites, government of Kenya data base, and other online publications. In-depth interviews were conducted using a small number of respondents that can provide information concerning a specific idea, or situation. Focus group approach which employs semi-structured group interview was used in this study as well. The researcher conducted four focus groups discussions and out of the four focus groups, two of these were held with participants from surrounding host community villages (Kakuma Town and surrounding villages), and two with refugees from Kakuma. The table below demonstrations the focus group discussion participants used.

Table 2. Focus groups

\begin{tabular}{ll}
\hline Host Community & Refugees \\
\hline 1. Adults and Youths & 1. Adults and Youths \\
2. Village elders/Clergy & 2. Camp elders \\
\hline
\end{tabular}

Note: Refugees and Host community were selected randomly 


\subsection{Conceptual Framework}

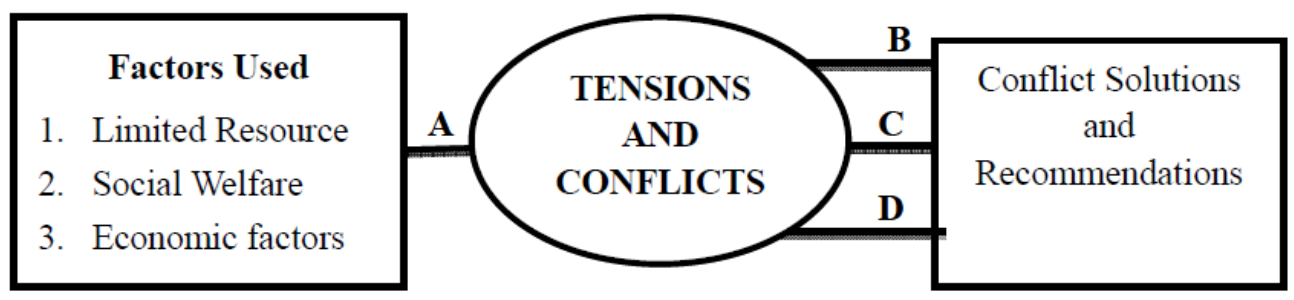

Figure 2. Conceptual framework

\section{Note:}

A - The causes of Tensions and Conflicts in Kakuma Refugee Camp

B - Represents the refugees' aid agencies' and government efforts to solve the tensions and conflicts respectively.

C - Represents refugees and host community ways of solving the tensions and conflicts.

D - Represent researcher's recommendation to solve the conflicts.

The Limited Resources Factors in this study include important factors such as land, water, forest and forest. The influx of refugees in larger numbers increases the populace of a given area and this can generate problems to the host community in terms of placing more pressure on already scarce resources. In addition, due to scarcity of resources in areas that refugees placed to live, the refugees and the host communities often are in conflicts as they continue to exert pressure on those resources and which in the long run may end up draining them. These limited resources were found to be the major source of tensions and conflicts with high magnitude within and outside Kakuma refugee camp.

Social Welfare Factors are things such as traditional communal movement that approves plea in social relationships and this study focused on health, education, sports and transport facilities. The social services provision to the refugee in Kakuma camp has not been an easy task since continuous influx of refugees is still witnessed and this escalates competition for the limited resources. The Host community does not have these facilities and are forced to go and share with the refugees which in most cases results to tension and conflicts. The inequities existing between refugees and host community normally leads to the increase of social tensions (Betts, 2009).

Economic Factors, the continuous insecurity and conflicts in Kenya's neighboring countries such as Somalia, South Sudan and Ethiopia has not only led to driven up inflation, worsened fiscal and financial positions but it has also led to tragic loss of life and physical destruction especial in the coast and north-eastern regions. Large population of refugees, weak security, and declining social cohesion has weakened the quality of institutions and their ability to commence much-needed economic reforms. The host-country incomes and expenditures rise when the refugees' demand increases. This is because an additional round of expenditure brings direct effect to the local economy. 
The huge influx of refugees to Kenya has brought competition between local citizens and refugees over essential resources such as food, water, housing, land and basic social amenities such as health centers. This with time will cause inflationary pressures on prices of goods and services and reduce wages. For example increase demand for food and other essential commodities automatically leads to price rise in the market which the will stimulate local economic activity although not the poorest population in the country. It is clear that hosting of refugees forces the hosting country to spend more on security, infrastructure, housing, water suppliers and food. The current economic challenges faced by almost all nations around the globe has made the nations hosting refugees to expect less help from the international community to compensate them on costs incurred in providing asylum for the refugees. Although hosting of refugees does not always bring negative effects but sometimes bring positive as well. In Kenya situation it seems negative impacts are more than positive ones.

\section{Study Results of Causes of Tensions and Conflicts}

This part presents results or findings of the study on the causes of refugees and host community conflicts in Kakuma refugee camp. The results and discussion here is based on the conceptual framework that includes; political and security, limited resources, social welfare, and socio-cultural factors. In addition, the current measures undertaken to minimize conflicts and researcher recommendations are also given. The host-community's members were asked about the influence of refugees to their daily lives and they gave both negative and positive results. The answers received from host-community focus group recognized a number of problems through answering question asked to them. It believed that refugees worsen ethnic tensions, deepen economic rivalry with locals, and expand rebellious social networks by transporting weapons and using camps to recruit and haven fighters (Shaver \& Zhou, 2015). The government often constructs refugee camps where the local host communities are more penurious and side-lined than the refugees themselves. The support that refugee get is far better than what the local host community get, for example delivery of relief food, access to resources and built structures many a times create violence between the two groups (Aukot, 2003).

\subsection{Limited Resource Factors}

The influx of refugees in larger numbers increases the populace of a given area and this can generate problems to the host community in terms of placing more pressure on already scarce resources. In addition, due to scarcity of resources in areas that refugees placed to live, the refugees and the host communities often are in conflicts as they continue to exert pressure on those resources and which in the long run may end up draining them. These limited resources include; land, water, forest destruction and collection of firewood.

Water is one of crucial resource that is significant for our existence since without water we cannot exist. In the recent years various publications about refugees indicate water as a significant source of tension between refugees and host communities (Card 1990; Farishta 2014; Landau 2002; Whitaker 2003). The demand for this precious commodity by both the refugees and the host community has impelled the refugees' organizations to dig water boreholes and in some cases put up tap water for both groups. Even with this development, the conflict between the refugees and the host community has not been determined 
completely and this implies that competition for this scarce resource remains as a major sources of conflicts in Kakuma area. In addition, due to the rising populace of refugees in the camp, together with the new influxes of refugees and already established refugees always fetch water from the nearby River (Tarach). River Tarach is a seasonal river which is the only source of water to both the host community and the refugees in Kakuma area.

"UNHCR has built water taps and pumps in the refugee camp but still we normally see refugees coming to river Tarach to fetch water for domestic usage. Sometimes misunderstanding between the host community and the refugees arises on who has the right to fetch water first causing them to fight a times" (Jacob, Host community Youth Representative, June 2017).

Wood from forests is another resource that occasionally causes conflicts around the refugee's camps. The host community and the refugees regularly used wood for domestic purposes for example; cooking, heating, lighting and building semi-permanent shelters. This study found out that the host community also used wood as source of income whereby building sticks, firewood and charcoals are sold for the purposes of getting income. The refugees and the host community population cut or use woods from the nearby shrubs and forests resulting to conflicts since the host feel bitter about the cutting of trees (Kumssa, Jones, \& Herbert, 2009). The trees and shrubs around the camp are disappearing, the situation is abysmal that even livestock leave a lone the people cannot find trees' shade to protect them from hot heat especially during the afternoon hours. During the interview and focus group discussion with the host community it was clear that many trees and shrubs are being cut daily.

"Let me tell you, big trucks and even people carrying dry or wet woods to the camp is seen on daily basis. Deforestation has become a reality here, trees are disappearing and soon or later we would not see trees around the camps, (Lokai, Host Community Elder, June 2017)."

The women of the local community every morning can be seen carrying building sticks to camp.The researcher one time stopped some of them and asked where they were talking the trees sticks and responded by saying that they said that they were taking them to Kakuma refugee camp to sell them. This implies that the local community too cut trees for economical purpose so as to earn a living. This can explain why there exists conflict between the refugees and the host community especially on who can collect and cut the wood from the forest. This is a complex situation at the moment, UNHCR previously tried to reduce the tension and conflicts by giving firewood contracts to the host community' organized groups to supply wood to the camp. There is no doubt deforestation is occurring around Kakuma camp at a very high rate and very soon the place will be a desert if no suitable measures are put in place.

Land usage is a limited resource that causes conflicts. The host community and refugees use land for grazing their animals, cultivating their crops and building the shelters on. The host community has been removed by force from their ancestral land by Kenya' government authorities to give room for the settlement of refugees. The free movement of the host community becomes restricted in certain areas where the camp is situated for example; where aid agencies offices are locates and others important structures (Ikanda, 2008). This has created rancor that has caused frequent conflicts seen between the refugees and the host community. This is what host community women representative had to say; 
"The refugees hosted in Kakuma camp have destroyed our grazing lands and farming fields along river Tarach in Kakuma. Our government and UNHCR decided to build this camp here, now our animals have no place to grazing lands." (Esther, Host Community Women Representative, June 2017)"

In addition, livestock theft of the host community by refugees' organized gangs has become as a source of tension and conflict within and around Kakuma area. A number of host community members living in Kakuma villages such as Narukorukodapal, Nadapal and Kakuma town. The concern members expressed their anger and hate on the refugees especially in disappearance of their livestock which they believe it is been stolen by refugees from the camp in the nearby grazing lands and forest.

"Livestock theft here in Kakuma has become a big problem and a matter of concern since refugees came. (Atapar, Host Community Women Representative, June 2017)."

\subsection{Social Welfare Factors}

Social welfare factors are things such as conservative social movement that endorses appeal in social relations and this study concentrated on health, education, sports and transport facilities. Providing social services to the refugee in Kakuma camp has been a difficult tasks since new arrivals of refugees is still witnessed and scrambling for the limited resources. Host-community (Turkana) does not have these facilities and are forced to go and share with the refugees which in most cases results to tension and conflicts. The inequities existing between refugees and host community habitually leads to the increase of social tensions (Betts, 2009). Turkana County is the second largest county out of 47 counties in Kenya. It is $77,000 \mathrm{~km} 2$ with a population of 855,399 as per 2009 census and means that the population is sparsely populated. This means that the host community members have to walk or go as far as $50 \mathrm{~km}$ to get health facilities and in Kakuma area, the host community members have to go to health facilities situated in the camp. Sometimes the host community and the refugees quarrel over who should be served first therefore causing tension and conflicts. During interviews with some of the refugees' representative, it was clear the host community do go to the camp to get health services.

"UNHCR should not allow the Turkana community (the host) to come to the camp and gate treated. It is sad some of us we have to wait in long queues as result of allowing the Turkana community to share with us the hospital services.'

(Fatumah, Refugee Women Representative, July 2017).”

Other social welfare factors include education, sports and transport facilities. Refugees' children prefer to enroll at Kenya primary and secondary schools with boarding facilities and this normally makes the host to feel bad since these schools are few and not enough for them. The parents of both the refugees and the host community do quarrel because of the situation in these boarding schools whereby they become congested. Also, the host community youth prefer going to the camp to learn at the vocational colleges such as Don Bosco although it is restricted to the refugees. The host community feel left out from benefiting from the services rendered to the refugees in the camp and this also causes dissatisfaction and conflict sometimes. When it comes to sports, youth from both do quarrel or fight when they want to use football fields or indoor grounds. Lastly, both refugees and the host community do use 
public transportation and sometimes the local community feels that they cannot travel together with the refugees in one car or bus. This is one source of quarrel and conflicts since the host feel they are in their own country and they are entitled to use the transportation service.

"Our children do share boarding schools with refugees' children and therefore congesting them. We do not want our children to share schools with refugees since schools look like prison. The refugees' also do not want our big children to join Don Bosco training institute in the camp." (Chris, Host Community Elder, June 2017).

\section{Current Measures to Solve the Conflicts}

This study found out that there are over 25 refugees' aid agencies that provide assistance refugees in Kakuma camp and they also put programs to try to solve conflicts between the refugees and the host community. The following are the current projects and measures used to reduce refugees-host community tensions and conflicts.

1) To solve fight over woods collect, UNHCR have given firewood contracts to organized host-community groups so as to supply the wood to the refugee camp. This has reduced refugees and host community quarrels and fights over collection of woods in the forest.

2) Catholic Mission has put up a vocational training Center - Don Bosco Vocational Training Center (DBVT) in the camp. This center provides technical training to the refugees giving them practical skills in various fields.

3) Information Communication Technology (ICT) Bootcamp program is one of the programmes used by various aid agencies such as Vodafone foundation and UNHCR, started to empower refugees' youths more specifically girl child to have information communication technology skills that will help them develop marketing skills to start their businesses (Otieno, 2017). Bootcamp offers a chance for the girls to gain exposure to some of the newest ICT inventions such as web design and development, digital art creation, basic computer and coding skills (Otieno, 2017).

4) Refugee-Host Community Project (RHCP) is one project that was started by United Nations Development Programme (UNDP) to reduce conflicts with a goal to improve the living conditions of the refugees and the host communities around the camps. The programme provides social services, encourage peaceful co-existence, provide skills on management and help the refugees and the local community to become self-reliant.

5) Lastly, UNHCR and Turkana County authorities have started a new camp (kalobeyei) near Kakuma refugee camp. The main aim is to decongest Kakuma refugee camp which is already congested. The overall goal of this new camp is not only to reduce the populace of refugees living in the camp but it is also meant to re-orient the refugees help program which add value to the improvement of socio-economic conditions to both the refugees and the host community.

\subsection{Recommendations}

Over 25 refugees' aid agencies in Kakuma can do more than what they are doing currently not only to the refugees but to the host community. The limited resources, facilities and services should be made available to both the host community and the refugees. Even though many publications have been published on the impacts of interactions between the host 
community and the refugees, so far there is little evidence showing how the host community benefit and to what extend (UNHCR, 2015). In order to reduce tension and conflicts, this study recommends the following;

1) The government and all refugee aid agencies should come up with programmes that benefit not only the refugees but the host community as well. The current refugee aid agencies and donor nations tailor their help towards the refugees only which should not be the case.

2) Aid agencies should build more schools especially vocational training colleges that should enrol youth from both the host community and the refugees. This will enable the youth to interact and embrace each other as they study together.

3) The government and UNHCR should try to minimize inequality created by providing essential goods and services to the refugees in the camp. Relief food and health facilities should also be made available to the host community.

4) Lastly, the government of Kenya through various government agencies should create awareness on the importance of protecting forests and effects of deforestation. The same massage should be passed on to the refugees as well and alternative means of cooking fuel should be given to refugees.

\subsection{Conclusion}

This study main objective was to find out what factors causes conflict between the refugees and host community and the same time explaining the current measures used to solve the conflicts. In order to achieve this goal, the study used both primary and secondary data collection methods. The study categorized factors causing conflicts into three main categories; limited resources, social welfare, and economic factors. In overall, limited resources such as water, wood and land were the main cause of tensions and conflicts within and around the camp. There is no doubt high population and increasing influx of refugees is putting lots of strain on vital resources as food, shelter and on sharing of social services. This has created hostility between the host community and the refugees as they contest to access these limited resources. The outsiders and the established community who represent the refugees and the host community respectively as referred in Elias theory brings into picture how conflicts occurs when the two groups interact. According to Elias' theory inequality and uneven power distribution between outsiders and the established results to frequent tensions and conflicts.

The developed nations should support the developing nations not only by supporting them financial but also host refugees in their countries since refugees crisis has become a global problem. There should be refugees' aid paradigm shift from traditional support for the refugees only to support of both the refugees and the host community. This is supported by the Refugee Aid and Development (RAD) theory approach that advocates for the integration of emergency relief aid and developmental programmes that includes refugees and host communities. Therefore, the focus to solve the refugee-host conflicts should be on both the host community and the refugees. This in the long-run will stop or minimize the tensions and conflicts that may cause war or even death in these two communities living alongside each other in the same area. 


\section{Macrothink}

\section{Reference}

Adisa, J. (1996). Rwandan Refugees and Environmental Strategy in the Great Lakes Region: A Report on the Habitat/UNEP Plan of Action. Journal of Refugee Studies, 9(3), 326-334. https://doi.org/10.1093/jrs/9.3.326

Anderson, D. M., \& McKnight, J. (2014). Kenya at war: Al-Shabaab and its Enemies in Eastern Africa. African Affairs, 114(454), 1-27. https://doi.org/10.1093/afraf/adu082

Atim, G. (2013). The Impact of Refugees on Conflicts in Africa. Journal of Humanities and Social Sciences, 14(2), 4-9.

Aukot, E. (2003). It Is Better to Be a Refugee Than a Turkana in Kakuma: Revisiting the Relationship between Hosts and Refugees in Kenya. Refuge: Canada's Journal on Refugees, 21(3).

Betts, A. (2009). Development Assistance and Refugees, Towards a North-South Grand Bargain? Forced Migration Policy Briefing 2. Refugee Studies Centre, University of Oxford. United Kingdom.

Betts, A. (2004). The international relations of the "new" extraterritorial approaches to refugee protection: Explaining the policy initiatives of the UK government and UNHCR. Refuge: Canada's Journal on Refugees, 22(1).

Card, D. (1990). The impact of the Mariel boatlift on the Miami labor market. ILR Review, 43(2), 245-257. https://doi.org/10.2307/2523702

Champagne, B., Cobb, W. B., Kaplan, S., \& Morrison, D. (2005). Anatomy of a Terrorist Attack: An In-Depth Investigation into the 1998 Bombings of the US Embassies in Kenya and Tanzania. Ridgway Center for International Security Studies, (17).

Ek, R., \& Karadawi, A. (1991). Implications of refugee flows on political stability in the Sudan. Ambio, 196-203.

Farishta, A. (2014). The impact of syrian refugees on jordan's water resources and water management planning.

Hogenstijn, M., Van Middelkoop, D., \& Terlouw, K. (2008). The established, the outsiders and scale strategies: studying local power conflicts. The sociological review, 56(1), 144-161. https://doi.org/10.1111/j.1467-954X.2008.00780.x

Ikanda, F. N. (2008). Deteriorating conditions of hosting refugees: A case study of the Dadaab complex in Kenya.

Jorgensen, D. L. (1989). Participant observation. John Wiley \& Sons, Inc. https://doi.org/10.4135/9781412985376

Kirui, P., \& Mwaruvie, J. (2012). The dilemma of hosting refugees: a focus on the insecurity in north-eastern Kenya. International Journal of Business and Social Science, 3(8).

Kuhlman, T. (1990). Burden or boon? A study of Eritrean refugees in the Sudan. VU University Press.

Kuhlman, T. (1991).The Economic Integration of Refugees in Developing Countries: A Research model. Journal of Refugee Studies, 4, 1-20. https://doi.org/10.1093/jrs/4.1.1 


\section{Macrothink}

Journal of Social Science Studies

ISSN 2329-9150

2018, Vol. 5, No. 1

Kumssa, A., Jones, J. F., \& Herbert Williams, J. (2009). Conflict and human security in the North Rift and North Eastern Kenya. International Journal of social economics, 36(10), 1008-1020. https://doi.org/10.1108/03068290910984786

Landau, L. B. (2002). Document. The humanitarian hangover: Transnationalization of governmental practice in Tanzania's refugee-populated areas. Refugee Survey Quarterly, 21(1_and_2), 260-299.

Martin, A. (2005). Environmental conflict between refugee and host communities. Journal of peace research, 42(3), 329-346. https://doi.org/10.1177/0022343305052015

Morfor, M. K. (2012). Forced Migration: Socio-economic Implications for Hosts Communities in Southern and Northern Ghana. A published thesis for Master in International Social Welfare and Health Policy, Oslo University College

Muigua, K. A. R. I. U. K. I. (2006). Protecting Refugees Rights in Kenya: Utilising International Refugee Instruments: The Refugee Act 2006 and The Constitution of Kenya as Catalysts.

My Government (MyGov). 2015. Statement by President Uhuru Kenyatta on the Terrorist Attack at Garissa University College.

Oka, R. C. (2014). Coping with the Refugee Wait: The Role of Consumption, Normalcy, and Dignity in Refugee Lives at Kakuma Refugee Camp, Kenya. American Anthropologist, 116(1), 23-37. https://doi.org/10.1111/aman.12076

Paige, Lavender. 2017. Read Donald Trump's New Order on Immigration.

Shaver, A., \& Zhou, Y. Y. (2015). Questioning refugee camps as sources of conflict. Unpublished manuscript.

Tollebrandt, S., \& Sophia W. (2013). Power Distribution Between Refugees and Tureti, M. K (2003). Impact of refugees on host communities: the case of Kakuma Refugee camp, North Western Kenya, 1992-2002 (Doctoral dissertation, University of Nairobi, CEES).

Tom, O. (2016). Kenya to Close Dadaab, World's Biggest Refugee Camo. AP News, UNHCR (2017). Figures at A Glance. Statistical Yearbooks. Available online at UNHCR website.

UNHCR. ( 2016). Global Trends: Forced Displacement in 2015.

UNHCR. (2015). "Worldwide Displacement Hits All-time High as War and Persecution Increase."

UNHCR. (2010). Refugee and Asylum Seekers in Kenya. Statistical Summary 28 February 2010

Whitaker, B.E. (2002). Tanzanian Refugees. Journal of Refugee Studies, 15(4), 339-340. https://doi.org/10.1093/jrs/15.4.339 


\section{Copyright Disclaimer}

Copyright for this article is retained by the author(s), with first publication rights granted to the journal.

This is an open-access article distributed under the terms and conditions of the Creative Commons Attribution license (http://creativecommons.org/licenses/by/3.0/). 